\section{DE- Al09-00SR22188 Journal Article}

Available online at www.sciencedirect.com

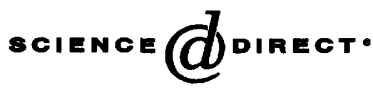

Forest Ecology and Management 228 (2006) 274-284
2006

06-22-P

Forest Ecology and Management

www.elsevier.com/locate/foreco

\title{
Implications of home-range estimation in the management of red-cockaded woodpeckers in South Carolina
}

\author{
Kathleen E. Franzreb * \\ USDA Southern Research Station, Southern Appalachian Mountains Cooperative Ecosystems Studies Unit, \\ Department of Forestry, Wildlife, and Fisheries, University of Tennessee, Knoxville, TN 37996, USA \\ Received 18 October 2005; received in revised form 9 March 2006; accepted 9 March 2006
}

\begin{abstract}
I undertook a behavioral study to determine red-cockaded woodpecker (Picoides borealis) home-range size at the Savannah River Site, South Carolina, USA. In this location, because much of the timber was harvested in the late 1940s and early 1950s, the available habitat largely consisted of younger trees (e.g., less than 45 years old), not generally considered prime habitat for this species. From 1992 to 1995 , I observed seven groups of red-cockaded woodpeckers to determine year-round home-range size. Most of the previous home-range studies on this species used the minimum convex polygon approach to estimate the size of the home range. I compared the minimum convex polygon and fixed kernel home-range estimation methods for each group. I found that the fixed kernel method gave consistently smaller estimates of home range than did the minimum convex polygon, a result directly related to the methodologies of the techniques. Mean home-range sizes for the $95 \%$ level were $56.9 \pm 5.2 \mathrm{S.E}$. ha with the fixed kernel versus $91.9 \pm 11.7$ S.E. ha with the minimum convex polygon. Core area $(50 \%)$ means were $4.5 \pm 0.5$ S.E. ha for the fixed kernel versus $16.7 \pm 2.4$ S.E. ha with the minimum convex polygon. It is recommended that future home-range studies use the fixed kernel estimator rather than the minimum convex polygon as it gives a more realistic and appropriate depiction of the area actually used by the birds within a given group. In estimating the number of groups that may be accommodated in a particular area, the mean home-range size as well as its shape need to be considered. Home-range size estimates at the Savannah River Site were similar to those obtained elsewhere in the species' range. Red-cockaded woodpeckers, in spite of the prevalence of relatively young forest structure, did not increase their home-range size to compensate for the paucity of older, more mature pine habitat.
\end{abstract}

Published by Elsevier B.V.

Keywords: Home range; Red-cockaded woodpecker; Minimum convex polygon; Fixed kernel estimator; Savannah River Site; South Carolina

\section{Introduction}

The red-cockaded woodpecker evolved in fire-maintained pine ecosystems within the southeastern United States (Conner et al., 2001). Primarily because of widespread modification and loss of its habitat and range, its apparent rarity, and decline in local populations, the U.S. Fish and Wildlife Service declared the species to be endangered in 1970 (35 Federal Register 16047,13 October 1970). By 1986, the population of redcockaded woodpeckers at the Savannah River Site, South Carolina, had dwindled to four birds. At that time an intensive effort was undertaken to try to prevent the species from becoming extirpated from the site, an effort that has proven successful (Franzreb, 1997). Part of this effort entailed

\footnotetext{
* Tel.: +1 865974 0932; fax: +1 8659461131.

E-mail address: Franzreb@utk.edu.
}

discovering more about the foraging behavior and home-range requirements of the bird at this location.

The majority of the Savannah River Site was harvested for timber in the late 1940s and early 1950s in the course of the sale of this land by private landowners to the Federal government. When this study began in 1992, most of the land on the site had been regenerated using several pine species. The resulting forest stands generally were less than 45 years old. Redcockaded woodpeckers use live pine trees as their primary foraging substrate (Hooper and Lennartz, 1981; Porter and Labisky, 1986). Earlier habitat use studies in other portions of the species' range dealt primarily with areas that contained a substantially higher proportion of older (i.e., $60-80$ year-old) and larger trees (Hooper and Lennartz, 1981; DeLotelle et al., 1987; Engstrom and Sanders, 1997; Zwicker and Walters, 1999; Walters et al., 2000, 2002) in comparison with the tree distribution by age and size at the Savannah River Site. Would red-cockaded woodpeckers increase their home-range sizes to 
Table 1

Vegetation distribution by forest type and age class (area in ha) on the Savannah River Site, South Carolina for 1992

\begin{tabular}{|c|c|c|c|c|c|}
\hline \multirow[t]{2}{*}{ Forest type $^{\mathbf{a}}$} & \multicolumn{4}{|c|}{ Age class (years) } & \multirow[t]{2}{*}{ Total (ha) } \\
\hline & $0-5$ & $5-25$ & $25-45$ & $>45$ & \\
\hline Longleaf pine (Pinus palustris) & 4390 & 876 & 8843 & 2454 & 16563 \\
\hline Slash pine $(P$. elliotii $)$ & 30 & 153 & 7981 & 504 & 8668 \\
\hline Loblolly pine ( $P$. taeda) & 4266 & 8687 & 9783 & 3011 & 25747 \\
\hline Longleaf pine-scrub oak & 1 & 0 & 152 & 58 & 211 \\
\hline Mesic pine-hardwood & 40 & 249 & 951 & 1283 & 2523 \\
\hline Upland hardwood & 49 & 15 & 633 & 1777 & 2475 \\
\hline Bottomland hardwood & 221 & 1811 & 1251 & 11032 & 14315 \\
\hline Cypress-tupelo (Taxodium distichum-Nyssa aguatica) & 27 & 0 & 85 & 2558 & 2670 \\
\hline Total (ha) & 9026 & 11790 & 29681 & 22677 & 73174 \\
\hline
\end{tabular}

Modified from White and Gaines (2000).

a Derived from either single or combined forest types used by the USDA Forest Service. Area estimates are derived from 1997 Continuous Inventory of Stand Conditions (CISC) data from the Savannah River Site, with age classes modified to reflect stand ages in 1992.

accommodate habitats that largely consisted of younger growth forest stands?

When this study began, the U.S. Forest Service (Region 8) standards and guidelines for the red-cockaded woodpecker specified maintaining 50 ha of foraging habitat per group (see U.S. Fish and Wildlife Service, 1985). However, the 50 ha figure was not universally accepted and, in fact, was challenged (Ligon et al., 1986; Jackson, 1986; Reed et al., 1988).

The objectives of this study were to determine year-round home-range size of red-cockaded woodpeckers at the Savannah River Site to determine if they were similar to those in areas of more mature forest stands and to derive a home-range size. In addition, I wished to compare two home-range sampling methods, the widely used minimum convex polygon method (Mohr, 1947) and the fixed kernel estimator method (Worton, 1989). There is widespread use of the minimum convex polygon approach in red-cockaded woodpecker home-range studies, but its limitations make for an interesting comparison with the recently developed fixed kernel method. Further, I wished to determine if home-range sizes at the Savannah River Site were different than seen elsewhere within the species' range considering the availability and distribution by age and size class of pines trees for foraging. Lastly, I wanted to assess how the shapes of the home ranges differ among red-cockaded woodpecker groups in this area.

\section{Methods and materials}

\subsection{Study site}

The Savannah River Site, a National Environmental Research Park, lies within the Upper Coastal Plain Physiographic Region in Aiken, Allendale, and Barnwell counties in South Carolina. In the early 1950 s, the land now known as the Savannah River Site was purchased by the Department of Energy (DOE) to be developed into a nuclear production facility. At that time, most of the site was in agricultural use or had been harvested for timber. Since 1952, the U.S. Department of Agriculture Forest Service has managed the natural resources of the site for DOE under an interagency agreement. The area managed for woodpeckers contains 31,970 ha of pine forest consisting of longleaf (Pinus palustris) (37.7\% of the pine acreage), loblolly $(P$. taeda) $(45.4 \%)$, slash $(P$. elliotii) (13.4\%), and other pines $(0.2 \%)$, in addition to pine-hardwoods (3.3\%) (Gaines, U.S. Forest Service, unpublished data). The site contains some residual older pine trees, although the majority of pine stands now present are the result of replanting efforts undertaken in the 1950s. In 1992, when this study began, the majority $(88.3 \%)$ of hectares replanted in pine on the site were less than 45 years old (Table 1).

\subsection{Red-cockaded woodpecker observations}

Each red-cockaded woodpecker on the site was banded with a unique set of colored, plastic leg bands for field identification and also with a numbered aluminum leg band provided by the U.S. Geological Survey. I obtained the necessary endangered species permits and banding permits from the U.S. Fish and Wildlife Service, U.S. Geological Survey, and State of South Carolina.

In this study, I used the definition of home range given by Wilson (1975) as, "an area that an animal learns thoroughly and habitually patrols" in contrast to a territory which is an "area occupied more or less exclusively by an animal or group of animals by means of repulsion through overt defense or advertisement."

I selected seven groups of red-cockaded woodpeckers on the Savannah River Site for intensive observation of their foraging behavior and other activities. Groups were randomly selected for study from those groups in which pairs maintained home ranges for at least the previous 2 years to maximize the likelihood that the group would persist throughout the course of the entire study period. Each group consisted of a breeding male and breeding female and often at least one helper bird. For groups 3 and 6, there was no turnover in either member of the breeding pair. For five of the seven groups, the male breeder remained the same. The breeding female varied from a group that had no turnover during the study, to changing every 
breeding season (group 2). During most years, group compositions included at least one helper and there was no group that did not have a helper in at least one of the years.

Observations of individuals were obtained from 5 May 1992 to 26 July 1995. For each observation, the bird's location was determined using a global positioning system (GPS) Trimble Pathfinder Professional (use of brand names does not convey any recommendation by the U.S. Forest Service). Observations were obtained for all members of the red-cockaded woodpecker groups. Group members tend to forage close to one another and may even forage in the same tree concurrently. Data were collected during all seasons of the year and all times during the day and were analyzed collectively for each group. Sequential observations were at least $15 \mathrm{~min}$ apart to minimize interdependence of subsequent observations (Hejl et al., 1990). Porter et al. (1985) reported that a 15-min interval between sequential observations of the same red-cockaded woodpecker was sufficient to consider the observations independent. Birds were observed from the time of leaving the roost cavity in the morning until, if possible, they returned to their cavities at night.

\subsection{Estimation of home-range size and shape}

I calculated overall home-range size for each red-cockaded woodpecker group using both the minimum convex polygon (Mohr, 1947) and fixed kernel (Worton, 1989) estimators. The minimum convex polygon typically is constructed by connecting the outermost points of a set of locations. As the $100 \%$ minimum convex polygon includes all observations, it contains some locations that may be considered "outliers", that is, points that represent areas that were infrequently used by the birds. I considered the outermost $5 \%$ of the point locations to be outliers. The fixed kernel technique was selected because it is considered the most robust of the various home-range estimators (Seaman and Powell, 1996). I calculated 95 and $50 \%$ (core) home-range sizes for the minimum convex polygon and fixed kernel estimators using the Animal Movement Extension (Hooge and Eichenlaub, 2000) to ArcView 3.2 (ESRI, 1997). I also estimated a $100 \%$ minimum convex polygon value so that I could compare my results with those of several other studies (Skorupa and McFarlane, 1976; Hooper et al., 1982; DeLotelle et al., 1987; Jackson and Parris, 1995; Engstrom and Sanders, 1997; Hardesty et al., 1997; Doster and James, 1998; Walters et al., 2002; Convery and Walters, 2004). Although there are numerous ways to define and calculate "core" areas (see Samuel et al., 1985), I used the definition of Cimino and Lovari (2003) as those areas encompassing 50\% of the animal's activity observations.

I obtained the Schoener ratio for each group's location data (Schoener, 1981) using the Animal Movement Extension home-range program. Schoener's ratio $\left(t^{2} / r^{2}\right)$ estimates the degree of temporal autocorrelation, where $t^{2}$ is the meansquared distance between successive observations and $r^{2}$ is the mean-squared distance between each observation and the geometric center of activity. Data with a ratio near 2 are considered independent (de Solla et al., 1999). If $t^{2} / r^{2}$ is less than 2, this would indicate that the sequential observations are positively serially correlated (de Solla et al., 1999), which may result in a negative bias and the resulting home-range value is likely to be an under-estimate of the true home-range size (Swihart and Slade, 1985a).

The kernel density estimator can be thought of as a series of raised areas placed over the fixes or locations of the observations, whereby the kernel function determines the shapes of the raised areas and the smoothing parameter determines their width (Silverman, 1986). This utilization distribution is a probabilistic model of home range that describes the relative amount of time that an animal is found in a particular place. As defined by Van Winkle (1975), the utilization distribution derived from the locations of an animal is "...the two-dimensional relative frequency distribution for the points of location of an animal over a period of time." Hence, the utilization distribution is defined by a probability density function, which describes how an animal uses the space within its home range and is the time an animal spends in a particular area. Smoothing parameters for fixed kernels were determined by least squares cross-validation (Seaman and Powell, 1996) and grid size was selected automatically by the home-range program. Kernel methods use a distribution function (the kernel probability matrix) to estimate the probability of finding an animal in a particular location, and then create the boundaries for the home range by connecting sites of equal probability (Worton, 1989). It is believed that at least 20 (Powell et al., 1997) or 30 (Seaman et al., 1999) locations or fixes are required for dependable fixed kernel estimates of home-range size.

To determine whether the shapes and degree of compactness of the home ranges and core areas differed among groups and the estimator selected, I used ArcView GIS to measure the perimeter of each home range, including cases where the home range consisted of several discrete areas. If two home ranges have the same area, the more compact one will have a smaller perimeter. The most compact shape for a home range is a circle as it contains the maximum area that a given perimeter can encompass. For each home range, I used the measured perimeter to calculate the area that this perimeter could contain if it were a circle. I then derived a "compactness ratio" by taking the actual home-range size and dividing it by the area of a circle obtained using the given perimeter. The compactness ratio has a maximum value of 1.0. The higher the compactness ratio for a home range, the more similar the shape of that home range is to a circle, indicating a more compact configuration. I obtained a mean compactness ratio for all home ranges with the 100,95 , and $50 \%$ minimum convex polygon and 95 and $50 \%$ fixed kernel estimators.

\section{Results}

\subsection{Minimum convex polygon and home-range shape}

The number of locations per group ranged from 773 to 891 with a total of 5874 observations for all groups (Table 2). Mean sample size of locations per group was 222.3 in 1992, 265.3 in 
Table 2

Home range and core area estimates for seven red-cockaded woodpecker groups in South Carolina using 50, 95 , and 100\% minimum convex polygon estimators

\begin{tabular}{|c|c|c|c|c|c|c|}
\hline \multirow[t]{2}{*}{ Group } & \multicolumn{3}{|c|}{$\begin{array}{l}\text { Home range } \\
100 \% \text { Minimum convex polygon }\end{array}$} & \multicolumn{3}{|c|}{$\begin{array}{l}\text { Home range } \\
95 \% \text { Minimum convex polygon }\end{array}$} \\
\hline & Size (ha) & Perimeter $(\mathrm{m})$ & Compactness ratio $^{a}$ & Size (ha) & Perimeter (m) & Compactness ratio $^{\mathrm{a}}$ \\
\hline 1 & 98.1 & 3721.6 & 0.89 & 51.2 & 2591.0 & 0.96 \\
\hline 2 & 200.7 & 5867.8 & 0.73 & 82.0 & 3334.5 & 0.93 \\
\hline 3 & 163.9 & 4809.9 & 0.89 & 118.3 & 3965.2 & 0.95 \\
\hline 4 & 184.2 & 5407.2 & 0.79 & 122.9 & 4165.0 & 0.89 \\
\hline 5 & 150.1 & 5040.4 & 0.74 & 90.9 & 3477.0 & 0.95 \\
\hline 6 & 203.3 & 5542.6 & 0.83 & 122.7 & 4072.6 & 0.93 \\
\hline 7 & 73.7 & 3365.3 & 0.82 & 55.2 & 2704.3 & 0.95 \\
\hline Mean \pm S.E. & $153.4 \pm 19.0$ & $4822.1 \pm 356.4$ & $0.81 \pm 0.024$ & $91.9 \pm 11.7$ & $3472.8 \pm 242.4$ & $0.94 \pm 0.009$ \\
\hline \multirow[t]{2}{*}{ Group } & \multicolumn{3}{|c|}{$\begin{array}{l}\text { Home-range core area } \\
50 \% \text { Minimum Convex Polygon }\end{array}$} & \multirow{2}{*}{\multicolumn{2}{|c|}{ Schoener's ratio ${ }^{b} t^{2} / r^{2}$}} & \multirow[t]{2}{*}{ Number of observations } \\
\hline & Size (ha) & Perimeter (m) & Compactness ratio $^{a}$ & & & \\
\hline 1 & 13.7 & 1327.0 & 0.98 & \multicolumn{2}{|l|}{0.57} & 857 \\
\hline 2 & 8.5 & 1047.9 & 0.97 & \multicolumn{2}{|l|}{0.39} & 799 \\
\hline 3 & 26.9 & 1861.3 & 0.98 & \multicolumn{2}{|l|}{0.29} & 891 \\
\hline 4 & 21.4 & 1674.1 & 0.96 & \multicolumn{2}{|l|}{0.35} & 860 \\
\hline 5 & 16.7 & 1469.4 & 0.97 & \multicolumn{2}{|l|}{0.41} & 885 \\
\hline 6 & 16.7 & 1474.7 & 0.97 & \multicolumn{2}{|l|}{0.27} & 809 \\
\hline 7 & 12.7 & 1284.5 & 0.97 & \multicolumn{2}{|l|}{0.55} & 773 \\
\hline Mean \pm S.E. & $16.7 \pm 2.4$ & $1448.4 \pm 100.5$ & $0.97 \pm 0.002$ & & & \\
\hline \multicolumn{6}{|l|}{ Total } & 5874 \\
\hline
\end{tabular}

a Compactness ratio = actual home-range size/maximum possible home-range size calculated from a circle with that perimeter.

b Schoener's ratio to determine if observations are independent (see text).

1993, 296.9 in 1994, and 55.0 in 1995. The sample size was smaller in 1995 than the previous years because the field data collection was concluded part way through the year. Schoener's ratio varied from 0.27 to 0.57 .

Using the $100 \%$ minimum convex polygon for the entire study period, home-range size ranged from 73.7 ha for group 7 to 203.3 ha for group 6 (Table 2), with an overall mean homerange size of $153.4 \pm 19.0$ (S.E.) ha (Table 2). When $5 \%$ of outliers were excluded from the data set, mean home-range size decreased to $91.9 \pm 11.7 \mathrm{ha}$, and ranged from 51.2 to 122.9 ha (Table 2). Thus, eliminating the outliers reduced the homerange size by approximately $40.0 \%$. The mean home-range size of the core area, containing one-half of the observations, was $16.7 \pm 2.4$ ha for the seven groups, which was $89.1 \%$ less than the mean $100 \%$ minimum convex polygon home-range estimate. Estimates of home-range size using the $50 \%$ minimum convex polygon ranged from 8.5 to 26.9 ha.

The perimeter of the $100 \%$ minimum convex polygon home ranges ranged from 3365.3 to $5867.8 \mathrm{~m}$, with a mean of $4822.1 \pm 356.4 \mathrm{~m}$ (Table 2 ). With the $95 \%$ minimum convex polygon, the mean perimeter was $3472.8 \pm 242.4 \mathrm{~m}$. The perimeter of the $50 \%$ minimum convex polygon averaged $1448.4 \pm 100.5 \mathrm{~m}$ (Table 2).

The smallest compactness ratio occurred for group $2(0.73)$ using the $100 \%$ minimum convex polygon and the highest occurred in groups $1(0.98)$ and $3(0.98)$ using the $50 \%$ minimum convex polygon (Table 2 ). The mean compactness ratio $(0.81 \pm 0.024)$ was the smallest for the $100 \%$ minimum convex polygon, intermediate for the $95 \%$ minimum convex polygon $(0.94 \pm 0.009)$, and highest for the $50 \%$ minimum convex polygon $(0.97 \pm 0.002)$ (Table 2$)$.

\subsection{Fixed kernel estimator and home-range shape}

Home-range estimates using the $95 \%$ fixed kernel ranged from 34.9 ha for group 2 to 73.3 ha for group 4 (Table 3 ). The mean home-range size for all groups was $56.9 \pm 5.2 \mathrm{ha}$. With the $50 \%$ fixed kernel, home-range sizes ranged from 2.3 ha for group 3 to 5.9 ha for group 5 (Table 3). The mean home-range size for all groups using the $50 \%$ fixed kernel was $4.5 \pm 0.5$ ha, which was $92.1 \%$ less than the mean for the $95 \%$ fixed kernel.

For the 95 and $50 \%$ fixed kernel method, the mean perimeters were $4872.9 \pm 493.2$ and $972.4 \pm 122.7 \mathrm{~m}$, respectively (Table 3 ). Home ranges calculated using the $50 \%$ fixed kernel were considerably more compact than those derived from the $95 \%$ fixed kernel based on the compactness ratio (mean $=0.68 \pm 0.096$ for the $50 \%$ versus mean $=0.33 \pm 0.043$, for the $95 \%$ fixed kernel) (Table 3 ).

\subsection{Comparison of estimators}

In comparing estimators, the minimum convex polygon consistently produced larger home-range estimates than did the fixed kernel approach (Tables 2 and 3). For each of the groups, the $95 \%$ minimum convex polygon provided larger estimates of home-range size than did either the $95 \%$ fixed kernel, $50 \%$ 
Table 3

Home range and core area estimates for seven red-cockaded woodpecker groups in South Carolina using 95 and $50 \%$ fixed kernel estimators

\begin{tabular}{|c|c|c|c|c|c|c|c|c|}
\hline \multirow[t]{2}{*}{ Group } & \multicolumn{3}{|c|}{$\begin{array}{l}\text { Home range } \\
95 \% \text { Kernel estimator }\end{array}$} & \multicolumn{3}{|c|}{$\begin{array}{l}\text { Core area } \\
50 \% \text { Kernel estimator }\end{array}$} & \multirow{2}{*}{$\begin{array}{l}\text { Schoener's } \\
\text { ratio }^{b} t^{2} / r^{2}\end{array}$} & \multirow[t]{2}{*}{$\begin{array}{l}\text { Number of } \\
\text { observations }\end{array}$} \\
\hline & Size (ha) & Perimeter (m) & Compactness ratio $^{a}$ & Size (ha) & Perimeter $(\mathrm{m})$ & Compactness ratio $^{a}$ & & \\
\hline 1 & 50.8 & 4401.1 & 0.33 & 4.5 & 1532.2 & 0.24 & 0.57 & 857 \\
\hline 2 & 34.9 & 3088.1 & 0.46 & 5.3 & 935.4 & 0.76 & 0.39 & 799 \\
\hline 3 & 71.3 & 5800.2 & 0.27 & 2.3 & 542.4 & 0.98 & 0.29 & 891 \\
\hline 4 & 73.3 & 5712.5 & 0.28 & 5.4 & 1134.1 & 0.53 & 0.35 & 860 \\
\hline 5 & 64.7 & 4895.3 & 0.34 & 5.9 & 1083.2 & 0.63 & 0.41 & 885 \\
\hline 6 & 56.0 & 6707.9 & 0.16 & 3.4 & 672.4 & 0.95 & 0.27 & 809 \\
\hline 7 & 47.4 & 3505.1 & 0.49 & 4.5 & 907.0 & 0.69 & 0.55 & 773 \\
\hline Mean \pm S.E. & $56.9 \pm 5.2$ & $4872.9 \pm 493.2$ & $0.33 \pm 0.043$ & $4.5 \pm 0.5$ & $972.4 \pm 122.7$ & $0.68 \pm 0.096$ & & 5874 \\
\hline
\end{tabular}

${ }^{a}$ Compactness ratio = actual home-range size/maximum possible home-range size calculated for a circle with that perimeter.

b Schoener's ratio to determine if observations are independent (see text).

minimum convex polygon, or 50\% fixed kernel (Figs. 1-7, Tables 2 and 3). Only in the case of groups 1 and 7 did the boundaries and area encompassed by the $95 \%$ minimum convex polygon approximately coincide with those of the $95 \%$ fixed kernel. For other groups, especially groups 2 and 6, the area circumscribed by the $95 \%$ fixed kernel was considerably smaller than that of the $95 \%$ minimum convex polygon. For six of the seven groups, the $95 \%$ fixed kernel had discontinuous boundaries and consisted of two or more discrete components. For the core areas ( $50 \%$ fixed kernel), five of the groups had only one discrete area, but group 1 had four discrete components (Figs. 1-7).

The 95\% fixed kernel estimator had the smallest mean compactness ratio followed by the $50 \%$ fixed kernel estimator. Regardless of the minimum convex polygon estimator used (50,

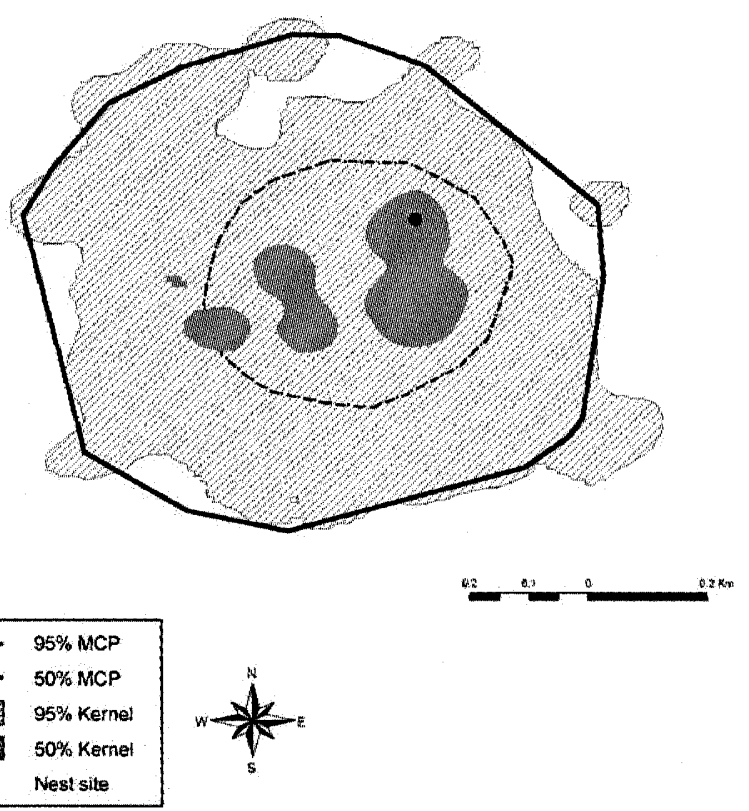

Fig. 1. Home-range boundaries of red-cockaded woodpeckers in group 1 at the Savannah River Site, S.C. obtained using four home-range estimators (50 and $95 \%$ minimum convex polygon and fixed kernel techniques).
95 , or $100 \%$ ), the resulting home-range shapes were consistently more compact than those obtained using the fixed kernel (Fig. 8, Tables 2 and 3).

\section{Discussion}

\subsection{Home-range sizes}

Several other studies have examined the year-round home ranges of red-cockaded woodpeckers and found them to range from 40.5 to 161.9 ha based on a variety of methodologies
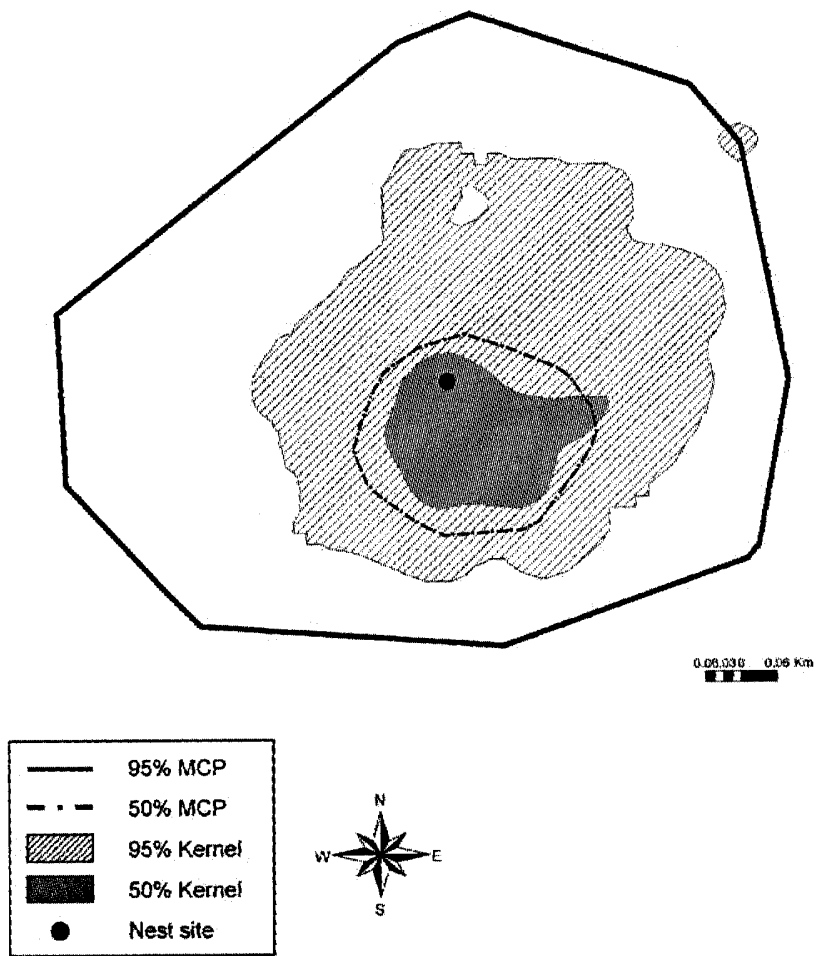

Fig. 2. Home-range boundaries of red-cockaded woodpeckers in group 2 at the Savannah River Site, S.C. obtained using four home-range estimators (50 and 95\% minimum convex polygon and fixed kernel techniques). 

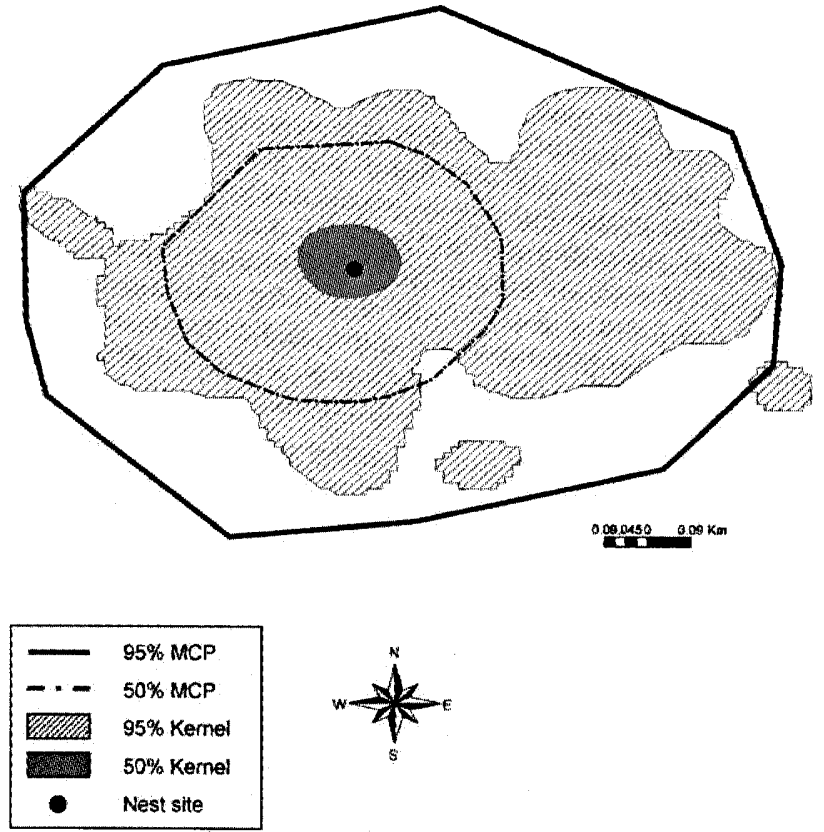

Fig. 3. Home-range boundaries of red-cockaded woodpeckers in group 3 at the Savannah River Site, S.C. obtained using four home-range estimators (50 and 95\% minimum convex polygon and fixed kernel techniques).

(USFWS, 2003). Hooper et al. (1982) estimated year-round home-range size to be $70.3 \mathrm{ha} \pm 35.7$ S.D. (range $=30-195 \mathrm{ha}$ ) for 24 groups on the Francis Marion National Forest in coastal South Carolina using a modified form of minimum convex polygon (excluding extra-territorial and limited use areas). In Florida, the mean home range for six groups was $150.0 \pm 32.9$ S.D. (range $=116.2-198.8 \mathrm{ha}$ ) based on the minimum convex polygon method (DeLotelle et al., 1987).

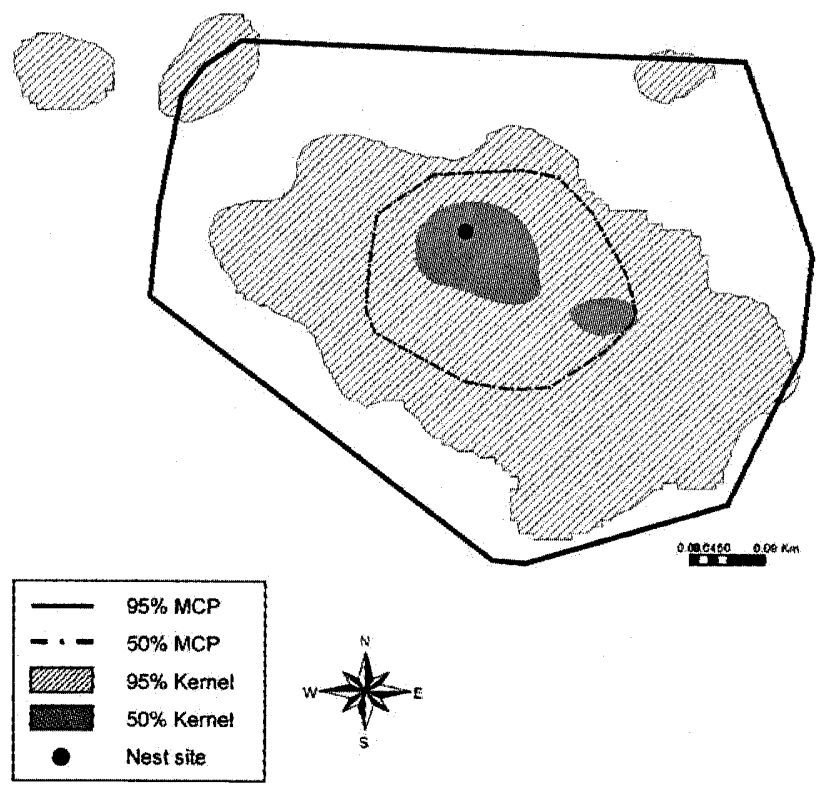

Fig. 4. Home-range boundaries of red-cockaded woodpeckers in group 4 at the Savannah River Site, S.C. obtained using four home-range estimators ( 50 and 95\% minimum convex polygon and fixed kernel techniques).
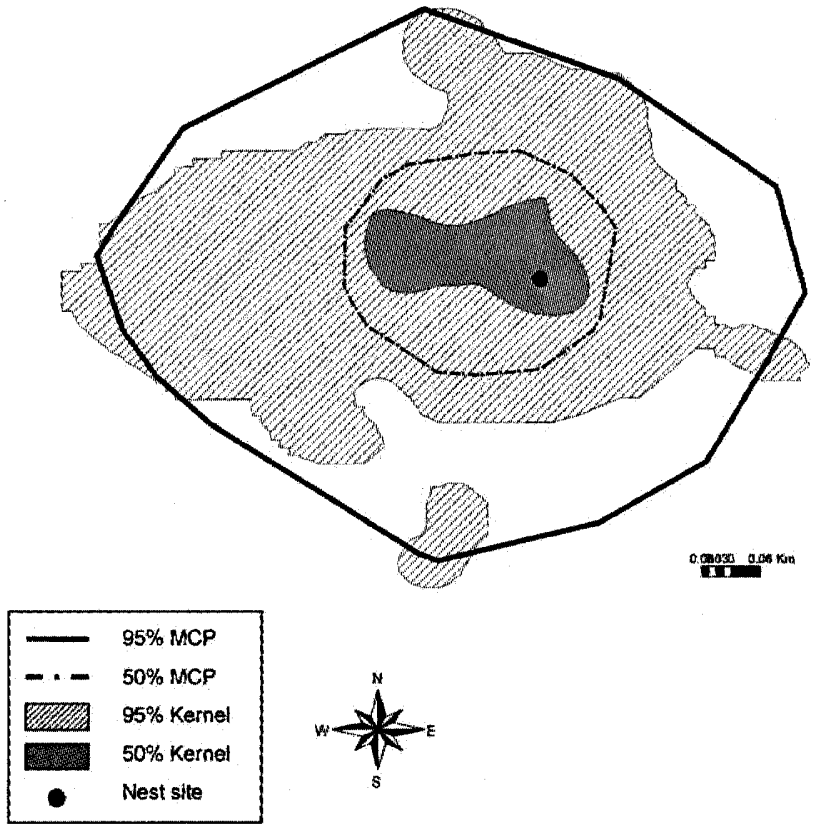

Fig. 5. Home-range boundaries of red-cockaded woodpeckers in group 5 at the Savannah River Site, S.C. obtained using four home-range estimators (50 and 95\% minimum convex polygon and fixed kernel techniques).

Engstrom and Sanders (1997) calculated a mean year-round home range of 47.1 ha for seven groups in Georgia (range $=23.2-61.9 \mathrm{ha}$ ) using a 95\% minimum convex polygon. On the Ouachita National Forest in west-central Arkansas, Doster and James (1998) mapped convex polygons and found that home ranges ranged from 17.1 to 42.5 ha. Jackson and
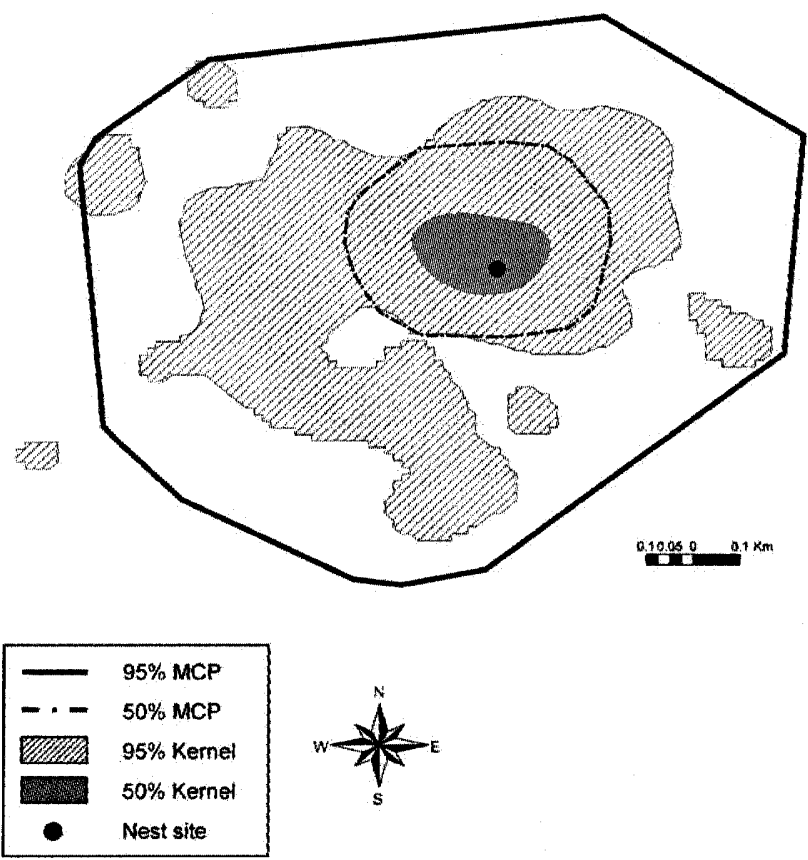

Fig. 6. Home-range boundaries of red-cockaded woodpeckers in group 6 at the Savannah River Site, S.C. obtained using four home-range estimators (50 and 95\% minimum convex polygon and fixed kernel techniques). 


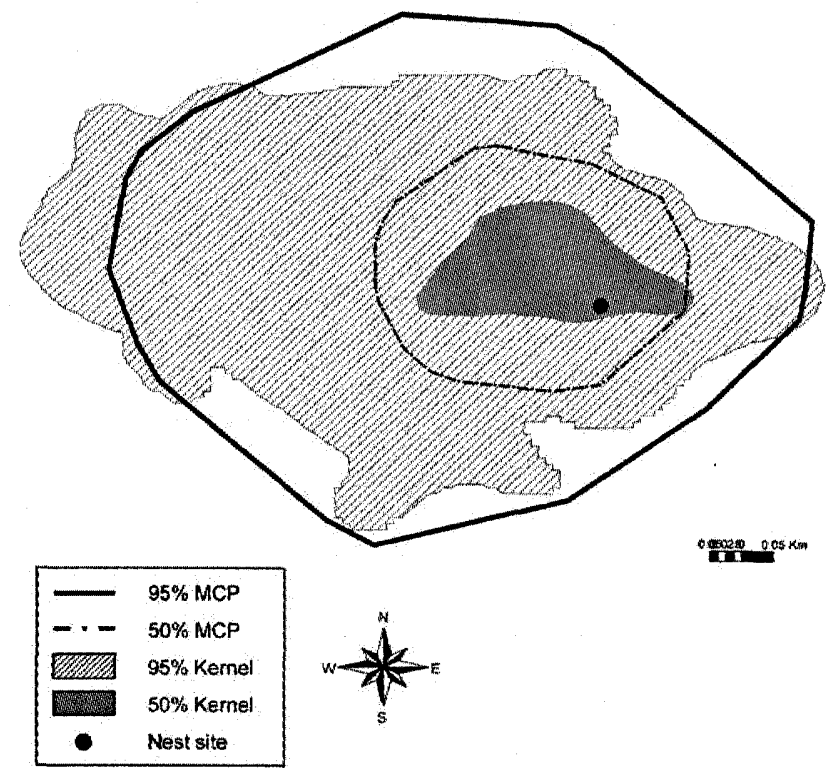

Fig. 7. Home-range boundaries of red-cockaded woodpeckers in group 7 at the Savannah River Site, S.C. obtained using four home-range estimators (50 and 95\% minimum convex polygon and fixed kernel techniques).

Parris (1995) reported that for three groups in Louisiana, the mean home ranges were 135 ha pre-timber harvesting (range $=109-170 \mathrm{ha}$ ) and $253 \mathrm{ha}$ post-timber harvesting (range = $115-413 \mathrm{ha}$ ) using the minimum convex polygon. The only other home-range study conducted at the Savannah River Site followed two groups of red-cockaded woodpeckers and mapped polygons of the locations (Skorupa and McFarlane, 1976). The maximum home range was 31.4 ha for one group and 33.6 ha for the other (Skorupa and McFarlane, 1976). These investigators all utilized some form of the convex polygon procedure. There was no consistency in how outliers were addressed or in how many of the observations were included (i.e., approaches ranged from using all observations to excluding areas of limited use and areas that were used by more than one group).

The mean home-range size obtained using the minimum convex polygon method in my study ( 91.9 ha) was in the middle of the values reported for other studies. Because my study encompassed a 36-month period, whereas the other

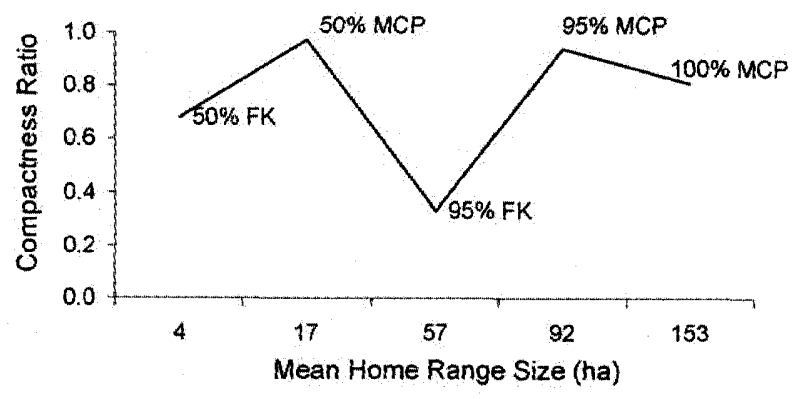

Fig. 8. Compactness ratio of home range in relation to home-range estimator and relationship of mean home-range size to home-range estimator used for seven groups of red-cockaded woodpeckers at the Savannah River Site, S.C. studies were of shorter duration, it is likely that the longer time frame resulted in larger home-range estimates for the groups at the Savannah River Site.

A few studies used an estimator other than the minimum convex polygon to determine red-cockaded woodpecker homerange sizes. Convery and Walters (2004) followed 23 groups during the non-breeding season at Camp Lejeune, North Carolina. They found a mean home-range size of 103.0 \pm 6.3 S.E. (range $=60.7-168.8 \mathrm{ha}$ ) using the $95 \%$ minimum convex polygon and a mean of $80.2 \pm 5.3 \mathrm{~S}$.E. (range $=39.0$ $145.4 \mathrm{ha}$ ) with the $95 \%$ fixed kernel estimator. Their analysis methodology was similar to mine in that they used the animal movement analysis extension and ArcView GIS and the least squares cross-validation approach. Home ranges were considerably smaller in my study area versus the Camp Lejeune study, which may reflect habitat quality. In a 2-year study, Hardesty et al. (1997) reported home-range estimates for 25 groups of red-cockaded woodpeckers on Eglin Air Force Base in northwest Florida. With the minimum convex polygon, they found that home-range size ranged from 51.6 to 240.8 ha (mean $=111.5 \pm 8.96$ S.D.). Combining both years, they noted that in 37 of 39 instances the minimum convex polygon gave larger estimates than the kernel method (Hardesty et al., 1997). In a study conducted in the North Carolina Sandhills, Walters et al. (2002) found that home-range size for 30 groups of redcockaded woodpeckers over a 2-year period averaged 126.2 ha (range $=83.8-232.1 \mathrm{ha}$ ) using the 95\% minimum convex polygon and 83.6 ha (range $56.3-128.7$ ha) using the $95 \%$ fixed kernel method. The results of these three studies are similar to mine in that the minimum convex polygon in almost all cases gave much higher home-range estimates than did the kernel method.

In comparing the boundaries of home ranges obtained using the $100 \%$ or the $95 \%$ minimum convex polygon to the $95 \%$ fixed kernel for the groups in my study, it is clear that the minimum convex polygon estimator included substantial areas that were not used or were rarely used by the birds. Thus, the minimum convex polygon in almost all cases provided an overestimate of home-range size.

\subsection{Home-range shapes}

The compactness ratio expresses how closely the actual home-range shape approximates that of a hypothetical circular home range of the same perimeter length. The closer the compactness ratio is to 1.0 , the more compact the home-range shape is as it more closely approximates the maximum size of a circle that can be derived from that perimeter. More compact home ranges with higher compactness ratios are more consolidated in comparison to home ranges that have either longer configurations and/or those that are more convoluted. In the case of the minimum convex polygon estimators, the most compact home ranges were those obtained using the $50 \%$ minimum convex polygon estimator. The home-range boundaries obtained from the $100 \%$ minimum convex polygon estimator included all values, even outliers, whose presence contributed to a more convoluted perimeter and, hence, a lower 
compactness ratio. Home ranges derived from the fixed kernel estimators, because they often consisted of multiple, discrete sections that were not contiguous (Figs. 1, 3-6), had higher compactness ratio values than those derived using the minimum convex polygon method.

\subsection{Mechanics of home rage estimators}

Within their home range or territory, animals generally move non-randomly. Hence, observers often must contend with autocorrelated data sets, which is especially true when frequent observations are obtained. Before home-range estimates are made, it is common to reduce or eliminate autocorrelation by subsampling (Worton, 1987; Ackerman et al., 1990; Kenward, 1992). Some researchers have suggested that the possible bias of autocorrelated data can be reduced by increasing the sampling interval until all locations are statistically independent. However, this does not appear to be necessary. Reynolds and Laundre (1990) and Otis and White (1999) have shown that increasing sampling effort in a particular time frame results in improved home-range estimates and, further, that demanding that all data be statistically independent would unnecessarily result in discarding biologically significant data. Location data that are obtained from sequential observations are more efficient to obtain and it has been found that the resulting homerange estimates do not differ significantly from estimates arising from independent locations (Anderson and Rongstad, 1989; Gese et al., 1990). In addition, de Solla et al. (1999) determined that home-range estimates using the kernel estimator do not require independence of sequential observations and also that their precision and accuracy actually increased with decreasing intervals between sequential locations. Swihart and Slade $(1985$ b, 1997) concluded that homerange estimation based on the kernel method is relatively robust and that any negative bias arising from possible nonindependence of location was minor.

Obtaining independence in data points has been deemed less crucial than obtaining an adequate sample of the animal's movement (Kernohan et al., 2001). Eliminating autocorrelated fixes from the data set obviously would reduce the sample size, but more importantly, would likely also adversely affect the biological significance of the results and reduce the accuracy of the home-range analyses. Schoener's ratio tests indicated that the data for each group of red-cockaded woodpeckers were autocorrelated. Based on the current information available on this subject, the 15 min interval between sequential location points in this study was deemed to not cause a problem with obtaining satisfactory home-range estimates. Moreover, the sample size in this study was large for each group, ranging from 773 to 891 observations. The substantial sample size helped to ensure that biologically meaningful home-range estimates were obtained.

Many wildlife studies report home-range estimates derived from more than one estimator (de Solla et al., 1999; Walters et al., 2002; Convery and Walters, 2004; Barg et al., 2005). Usually one of the referenced estimators is the minimum convex polygon as it is easy to compare among studies and is the most frequently used method (Harris et al., 1990; White and Garrott, 1990). The minimum convex polygon method provides an estimate of home-range size by determining the area of the smallest polygon formed by connecting the outermost locations. This process frequently provides overestimates of the home-range size because it includes so many unused areas (White and Garrott, 1990) as evidenced in the results of this study. Substantial disadvantages of the minimum convex polygon are that it is not capable of demonstrating how intensively different parts of the home range are used and that it is strongly influenced by the locations of the outermost points (Kenward, 1987). Although the minimum convex polygon can be used to locate the areas with the highest density of observations (Michener, 1979; Kenward, 1987), this requires repeatedly recalculating the home-range estimate after excluding a percentage of the outermost positions. As the number of observations increases, the size of the home range using the minimum convex polygon method usually increases too. Further, because it includes areas that are unused or rarely used, the minimum convex polygon is less suitable in terms of the biology of the species as a descriptive statistic (White and Garrott, 1990).

An advantage of the kernel method over the minimum convex polygon is how outliers affect the outcome. Because the kernel estimation method uses a utilization distribution with a probability level delineation (such as the $95 \%$ probability of occurrence), this method is relatively insensitive to the presence of outliers, which is not the case with the minimum convex polygon. Further, the use of kernel methods in preference to other techniques has been proposed because kernels are less biased by the chosen scale or grid density and can produce results that are more consistent (Worton, 1989; Kie et al., 1996). Fixed kernel methods are believed to produce area estimates with little bias when using the least squares cross-validation approach to select the smoothing parameter (Seaman and Powell, 1996).

\subsection{Management implications}

The choice of home-range estimator may have substantial implications regarding habitat management of red-cockaded woodpeckers. For example, if one wanted to estimate the number of groups that could be supported in a given area and used an inappropriate or unreliable home-range estimator, it is likely that the resulting estimate of the number of potential groups that could be supported would be grossly inaccurate.

Because of its many advantages as discussed earlier, I recommend using the $95 \%$ fixed kernel estimator. If the general area has fairly uniform, suitable habitat quality, the typical home-range configurations derived using the fixed kernel method are likely to consist of one discrete unit and be fairly compact in shape, with a relatively high compactness ratio. In such a situation, the manager/biologist may be able to reliably use the mean home-range size to estimate how many groups may be accommodated in the area being managed.

However, if the general area consists of a substantial amount of habitat of unacceptable quality, it is likely that the home-range 
configuration will have a more convoluted shape with a low compactness ratio as the fixed kernel estimator excludes areas with zero or low probability of use. For example, at the Savannah River Site, there were areas of suitable habitat mixed with areas of low suitability or unsuitable habitat. To manage for the typical home-range size of about $60 \mathrm{ha}$, it is necessary to take into consideration that these 60 ha are likely to be spread amongst multiple, discrete, non-contiguous areas. If one included the little used or unused areas in this situation, a group might fly over a much larger area, possibly 100 ha. It would be wise to factor the larger figure into any estimate of possible population size that an area could support.

The habitat within the home-range boundaries is invariably non-uniform, containing stands with trees of various pine species, sizes, and ages. Foraging red-cockaded woodpeckers respond to the available size and age classes of trees that are present in their home ranges and have been shown to prefer large, old trees in preference to small, young trees (Hooper and Lennartz, 1981; Porter and Labisky, 1986; DeLotelle et al., 1987; Bradshaw, 1995; Jones and Hunt, 1996; Engstrom and Sanders, 1997; Hardesty et al., 1997; Zwicker and Walters, 1999; Walters et al., 2000, 2002; Franzreb, 2004). Although it is not known whether it is tree age, size, or both age and size that determine tree use by foraging red-cockaded woodpeckers, it is clear that birds do not visit pine trees of all sizes and ages with equal frequency.

On the Savannah River Site, I found that foraging redcockaded woodpeckers avoided trees $<20.3 \mathrm{~cm}$ dbh, used trees $20.3-25.4 \mathrm{~cm} \mathrm{dbh}$ in proportion to, or more than, their availability, and strongly selected or preferred trees that were $\geq 25.4 \mathrm{~cm} \mathrm{dbh}$ (Franzreb, 2004). A preference or selection is indicated by use that is greater than predicted on the basis of resource availability. Unlike the results of most of the other studies, red-cockaded woodpeckers at the Savannah River Site did not avoid trees in the middle size class $(20.3-25.4 \mathrm{~cm} \mathrm{dbh})$, instead foraging in those trees in proportion to availability or at even higher rates. The Savannah River Site, including the seven home ranges in this study, was largely composed of regenerating stands of relatively young pine that were predominantly in the middle size class. Red-cockaded woodpeckers successfully reproduced in all seven of these home ranges (Franzreb, 1997).

Red-cockaded woodpeckers also have been shown to forage non-randomly with regard to tree age, in that they avoid younger trees and select trees in the middle-age, with a strong preference for older trees (Hardesty et al., 1997; Zwicker and Walters, 1999; Walters et al., 2000, 2002). In my study area, trees less than 29 years-of-age were avoided by foraging redcockaded woodpeckers, whereas trees 30-39 years old were used substantially more with respect to their availability, and trees $\geq 40$ years-of-age were strongly preferred (Franzreb, 2004). Red-cockaded woodpeckers on the Savannah River Site routinely foraged in trees that on average were much younger than those selected for foraging elsewhere in the range.

My results do not comport in their entirety with those of other workers as birds on the Savannah River Site foraged considerably more frequently in younger, smaller pine trees than has been regularly observed in other study areas, no doubt reflecting the age and size of pines that were available. The importance of my results is that red-cockaded woodpeckers apparently did not enlarge their home ranges to compensate for the relative paucity of older forest stands or larger, older trees.

To facilitate red-cockaded woodpecker management on the Savannah River Site, we are developing a model (RCWMOD) to predict species population size that integrates forest inventory data, future forest vegetation conditions, redcockaded woodpecker habitat standards (such as tree age and size of pine trees to determine suitable foraging habitat), and heuristic timber harvesting rules specific for this site through a spatially explicit GIS simulation (Franzreb, Parresol, Lloyd, Van Blaricom, in preparation). The model includes a component that estimates current stand conditions, allows the stands to develop through time, and then harvests specific stands according to a set of rules and habitat constraints. RCWMOD provides a landscape perspective and long-term prediction of habitat, which is otherwise unavailable to land managers when making individual stand prescriptions. Using established criteria, we will predict spatially suitable foraging and nesting habitat for red-cockaded woodpeckers at periodic time intervals ( 5 years) up to 20 years. RCWMOD operates on a realistic and dynamic landscape and, therefore, permits alternative harvesting strategies to be evaluated relative to a given set of habitat standards.

To use RCWMOD one must be able to evaluate each stand in terms of whether it is acceptable for foraging red-cockaded woodpeckers. Therefore, the information described above regarding the use of pine trees of various ages and size classes specific for the woodpeckers on the Savannah River Site is critical.

In addition to information on foraging behavior, it is also critical to have an accurate home-range estimate to get meaningful output from RCWMOD. The model evaluates the stands immediately surrounding an actual or potential nest tree (one nest tree per group) and determines if the stand is acceptable for foraging woodpeckers based on the foraging results. Adjacent stands are sequentially evaluated and, if rated as suitable for foraging, are added to the total area until there is enough acreage to equal the mean home-range size. At this point this home-range area is then regarded as suitable and capable of supporting a woodpecker group. This process is repeated throughout the area managed for red-cockaded woodpeckers on the Savannah River Site. The manager/ biologist is able to set the mean home-range size for RCWMOD to use to generate the population estimate. Therefore, it is essential that the most appropriate home-range estimator is selected as the output of the model is largely dependent on the value used for the typical home-range size. Using the best home-range estimator, in this case the $95 \%$ fixed kernel, will increase the reliability and accuracy of the population size that the model generates. RCWMOD incorporates and relies upon the results of my research on this species on the Savannah River Site in terms of both foraging behavior, habitat selection, and home-range characteristics. The fixed kernel estimator provides 
the manager/biologist with the tool to develop a realistic homerange size that is so crucial to the output of the model.

\section{Conclusions}

On the Savannah River Site, I suggest an estimate of homerange size of 60 ha per group for management purposes; however, it should be noted that the 60 ha may not be contiguous. The 60 ha estimate was based on my results for the mean $95 \%$ fixed kernel estimates ( $X=56.9 \pm 5.2$ ha). In some cases, a 60-ha home range may be contained within a considerably larger area as demonstrated by the home range of group 6 in this study (Fig. 6).

Comparisons of home ranges and habitat use among different research studies could be misleading if different home-range estimators were compared. The programs used to compute home ranges often use different default values and algorithms to arrive at a smoothing parameter, which may alter the outcome (Lawson and Rodgers, 1997). The technique used should be clearly stated, including the particular program selected and the appurtenant values so that investigators can begin to get a better idea of how home ranges really differ within the geographic range of the species. With the advent of more sophisticated computer software to calculate home-range sizes and shapes, it would behoove investigators to use a more enlightened approach than the minimum convex polygon, which consistently overestimates the actual area used by the birds.

Home-range delineations often are associated with habitat selection studies to allow comparison of "used" versus "available" habitat to arrive at selection and preference information. If the minimum convex polygon is the technique used for red-cockaded woodpecker home-range determinations, as was the case in the majority of published studies on this subject for this species, is it likely that the home ranges so designated included areas within the boundaries that were not used or little used by the birds. This would create a false impression of what actually constitutes habitat preferences. It is recommended that researchers in the future consider using the fixed kernel with least squares cross-validation in lieu of the more traditional minimum convex polygon as it presents a more accurate picture of the home range of this species.

Contrary to what may have been expected, foraging redcockaded woodpeckers at the Savannah River Site did not compensate for the relative paucity of older, more mature pine trees and the widespread presence of relatively young stands of pines by enlarging their home ranges. Further, the birds appeared to compensate, in part, by spending a larger proportion of time foraging in younger, smaller trees than what has been customarily observed elsewhere, demonstrating that rather than increase the home-range size, the birds displayed a substantial amount of flexibility in foraging behavior.

\section{Acknowledgments}

This research was supported by the Department of Energy, Savannah River Site, and its cooperation is gratefully acknowledged. I am especially grateful to S. Schulze for primary field support and the rest of my hard-working field staff whose efforts were crucial to the success of the red-cockaded woodpecker research at the site. I am grateful to K. Asmus for help with data analysis. Funding was provided by the Department of Energy-Savannah River Operations Office through the U.S. Forest Service Savannah River under Interagency Agreement DE-IA09-76SR00056. I thank J. Walters, F. Van Mannen, R. Thill, R. Epting, and J. Blake for reviewing the manuscript and $S$. Zarnoch for statistical review. The cooperation of the USDA Forest Service Savannah River is gratefully acknowledged (J. Irwin, E. LeMaster, W. Jarvis, G. Gaines, D. Wilson, and various other staff). In particular, I thank Dr. J. Blake, Savannah River Forest Station, for his long-standing support of my research on the site.

\section{References}

Ackerman, B.B., Leban, F.A., Samuel, M.D., Garton, E.O., 1990. User's manual for program Home-range. Technical Report 15. Forestry, Wildlife, and Range Experiment Station, University of Idaho, Moscow, p. 80.

Anderson, D.E., Rongstad, O.J., 1989. Home-range estimates of red-tailed hawks based on random and systematic relocations. J. Wildlife Manage. 53, 802-807.

Barg, J.J., Jones, J., Robertson, R.J., 2005. Describing breeding territories of migratory passerines: suggestions for sampling, choice of estimator, and delineation of core areas. J. Anim. Ecol. 74, 139-159.

Bradshaw, D.S., 1995. Habitat use by a relict population of red-cockaded woodpeckers in southeastern Virginia. In: Kulhavy, D.L., Hooper, R.G., Costa, R. (Eds.), Red-cockaded Woodpecker Recovery, Ecology, and Management. Center for Applied Studies in Forestry, College of Forestry, Stephen F. Austin University, Nacogdoches, Texas, pp. 482-488.

Cimino, L., Lovari, S., 2003. The effects of food or cover removal on spacing patterns and habitat use in roe deer (Capreolus capreolus). J. Zool. 261, 299-305.

Conner, R.N., Craig, D.C., Walters, J.R., 2001. The Red-cockaded Woodpecker-Surviving in a Fire-Maintained Ecosystem. University of Texas Press, Austin, Texas, p. 363.

Convery, K.M., Walters, J.R., 2004. Red-cockaded woodpecker home-ranges and foraging partition. In: Costa, R., Daniels, S.J. (Eds.), Proceedings of the Red-cockaded Woodpecker Symposium IV on Red-cockaded Woodpecker Road to Recovery. Savannah, GA, 2003. Hancock House, Blaine, WA, pp. 526-535.

DeLotelle, R.S., Epting, R.J., Newman, J.R., 1987. Habitat use and territory characteristics of red-cockaded woodpeckers in central Florida. Wilson Bull. 99, 202-217.

Doster, R.H., James, D.A., 1998. Home-range size and foraging habitat of redcockaded woodpeckers in the Ouachita Mountains in Arkansas. Wilson Bull. 110, 110-117.

Engstrom, R.T., Sanders, F.J., 1997. Red-cockaded woodpecker foraging ecology in an old-growth longleaf pine forest. Wilson Bull. 109, 203-217.

ESRI, 1997. Environmental Systems Research Institute Inc., Redlands, CA.

Franzreb, K.E., 1997. Success of intensive management of a critically imperiled population of red-cockaded woodpeckers in South Carolina. J. Field Ornithol. 68, 458-470.

Franzreb, K.E., 2004. Habitat preferences of foraging red-cockaded woodpeckers at the Savannah River Site, South Carolina. In: Costa, R., Daniels, S.J. (Eds.), Proceedings Red-cockaded Woodpecker Symposium IV on Redcockaded Woodpecker Road to Recovery. Savannah, GA, 2003. Hancock House, Blaine, WA, pp. 553-561.

Gese, E.M., Anderson, D.E., Rongstad, O.J., 1990. Determining home-range size of resident coyotes from point and sequential locations. J. Wildlife Manage. 54, 501-506.

Hardesty, J.L, Gault, K.E., Percival, F.P., 1997. Ecological correlates of redcockaded woodpecker (Picoides borealis) foraging preference, habitat use, and home range size in northwest Florida (Eglin Air force Base). Final 
Report Research Work Order 99, Florida Cooperative Fish and Wildlife Research Unit, University of Florida, Gainesville, Florida.

Harris, S., Cresswell, W.J., Forde, D.C., Trewhella, W.J., Woolard, T., Wray, S., 1990. Home-range analysis using radio-tracking data: a review of problems and techniques particularly as applied to the study of mammals. Mammal Rev. 20, 97-123.

Hejl, S.J., Verner, J., Bell, G.W., 1990. Sequential versus initial observations in studies in avian foraging. In: Morrison, M.L., Ralph, C.J., Verner, J., Jehl, J.R. (Eds.), Avian Foraging: Theory, Methodology, and Applications. Studies in Avian Biology, vol. 13. Cooper Ornithological Society, pp. 166-173.

Hooge, P.N., Eichenlaub, B., 2000. Animal movement extension to ArcView, version 2.0. U.S. Geological Survey, Anchorage, Alaska.

Hooper, R.G., Lennartz, M.R., 1981. Foraging behavior of the red-cockaded woodpecker in South Carolina. Auk 98, 321-334.

Hooper, R.G., Niles, L.J., Harlow, R.F., Wood, G.W., 1982. Home-ranges of the red-cockaded woodpeckers in coastal South Carolina. Auk 99, 675-682.

Jackson, J.A., 1986. Biopolitics, management of federal lands, and the conservation of the red-cockaded woodpecker. Am. Birds 40, 1162-1168.

Jackson, J.A., Parris, S.D., 1995. The ecology of red-cockaded woodpeckers associated with construction and use of a multi-purpose range complex at Fort Polk, Louisiana. In: Kulhavy, D.L., Hooper, R.G., Costa, R. (Eds.), Red-cockaded Woodpecker Recovery, Ecology, and Management. Center for Applied Studies in Forestry, College of Forestry, Stephen F. Austin University, Nacogdoches, Texas, pp. 277-282.

Jones, C.M., Hunt, H.E., 1996. Foraging habitat of the red-cockaded woodpecker on the D'Arbonne National Wildlife Refuge, Louisiana. J. Field Ornithol. 67, 511-518.

Kenward, R.E., 1987. Wildlife Radio Tagging, Field Equipment, Field Techniques, and Data Analysis. Academic Press, Toronto, Canada, p. 222.

Kenward, R.E., 1992. Quantity versus quality: programmed collection and analysis of radio-tracking data. In: Priede, I.G., Swift, S.M. (Eds.), Wildlife Telemetry: Remote Monitoring and Tracking in Animals. Ellis Horwood, Chichester, UK, pp. 231-246.

Kernohan, B.J., Gitzen, R.A., Millspaugh, J.J., 2001. Analysis of animal space use and movements. In: Millspaugh, J.J., Marzluff, J.M. (Eds.), Radio Tracking and Animal Populations. San Diego, pp. 125-166.

Kie, J.G., Baldwin, J.A., Evans, C.J., 1996. CALHOME: a program for estimating animal home-ranges. Wildlife Soc. Bull. 24, 342-344.

Lawson, E.J.G., Rodgers, A.R., 1997. Differences in home-range size in commonly used software programs. Wildlife Soc. Bull. 25, 721-729.

Ligon, J.D., Stacey, P.B., Conner, R.N., Bock, C.E., Adkisson, C.S., 1986. Report of the American Ornithologists' Union Committee for the conservation of the red-cockaded woodpecker. Auk 103, 848-855.

Michener, G., 1979. Spatial relationships and social organization of adult Richardson's ground squirrels. Can. J. Zool. 57, 125-139.

Mohr, C.O., 1947. Table of equivalent populations of North American small mammals. Am. Midland Nat. 37, 223-249.

Otis, D.L., White, G.C., 1999. Autocorrelation of location estimates and the analysis of radio tracking data. J. Wildlife Manage. 63, 1039-1044.

Porter, M.L., Collopy, M.W., Labisky, R.F., Littell, R.C., 1985. Foraging behavior of red-cockaded woodpeckers: an evaluation of research methodologies. J. Wildlife Manage. 49, 505-507.

Porter, M.L., Labisky, R.F., 1986. Home range and foraging habitat of redcockaded woodpeckers in northern Florida. J. Wildlife Manage. 50, 239-247.

Powell, R.A., Zimmerman, J.W., Seaman, D.E., 1997. Ecology and behavior of North American black bears: home-ranges, habitat and social organization. Chapman and Hall, London, UK.
Reed, J.M., Carter III, J.H., Walters, J.R., Doerr, P.D., 1988. An evaluation of indices of red-cockaded woodpecker populations. Wildlife Soc. Bull. 16, 406-410.

Reynolds, T.D., Laundre, J.W., 1990. Time intervals for estimating pronghorn and coyote home-ranges and daily movements. J. Wildlife Manage. 54, 316-322.

Samuel, M.D., Pierce, D.J., Garton, E.O., 1985. Identifying areas of core concentrated use within the home-range. J. Anim. Ecol. 54, 711-719.

Schoener, T.W., 1981. An empirically based estimate of home-range. Theor Popul. Biol. 20, 281-325.

Seaman, D.E., Powell, R.W., 1996. An evaluation of the accuracy of kernel density estimators for home-range analysis. Ecology 77, 2075-2085.

Seaman, D.E., Millspaugh, J.J., Kernohan, B.J., Brundige, G.C., Raedeke, K.J., Gitzen, R.A., 1999. Effects of sample size on kernel home-range estimates. J. Wildlife Manage. 63, 739-747.

Silverman, B.W., 1986. Density Estimation for Statistics and Data Analysis. Chapman and Hall, New York.

Skorupa, J.P., McFarlane, R.W., 1976. Seasonal variation in foraging territory of red-cockaded woodpeckers. Wilson Bull. 88, 662-665.

de Solla, S.R., Bonduriansky, R., Brooks, R.J., 1999. Eliminating autocorrelation reduces biological relevance of home-range estimates. J. Anim. Ecol. $68,221-234$

Swihart, R.K., Slade, N.A., 1985a. Testing for independence of observations in animal movements. Ecology 66, 1176-1184.

Swihart, R.K., Slade; N.A., 1985b. Influence of sampling interval on estimates of home-range size. J. Wildlife Manage. 49, 1019-1025.

Swihart, R.K., Slade, N.A., 1997. On testing for independence of animal movements. J. Agric. Biol. Environ. Stat. 2, 48-63.

U.S. Fish and Wildlife Service, 1985. Red-cockaded Woodpecker Recovery Plan. Atlanta, GA, p. 88.

U.S. Fish and Wildlife Service, 2003. Red-cockaded Woodpecker (Picoides borealis) Recovery Plan, 2nd ed. Atlanta, GA. 296 pp.

Van Winkle, W., 1975. Comparison of several probabilistic home-range models. J. Wildlife Manage. 39, 118-123.

Walters, J.R., Daniels, S.J., Carter III, J.H., Doerr, P.D., Brust, K., Mitchell, J.M., 2000. Foraging habitat resources, preferences and fitness of redcockaded woodpeckers in the North Carolina Sandhills. Fort Bragg Project Final Report. Virginia Polytechnic Institute and State University, Blacksburg, VA, and North Carolina State University, Raleigh, NC, p. 59.

Walters, J.R., Daniels, S.J., Carter III, J.H., Doerr, P.D., 2002. Defining quality of red-cockaded woodpecker foraging habitat based on habitat use and fitness. J. Wildlife Manage. 66, 1064-1082.

White, G.C., Garrott, R.A., 1990. Analysis of Wildlife Radio-Tracking Data. Academic Press, New York, USA.

White, D.L., Gaines, K.F., 2000. The Savannah River Site: site description, land use and management history. In: Dunning, Jr., J.B., Kilgo, J.C. (Eds.), Avian Research at the Savannah River Site: a Model for Integrating Basic Research and Long-Term Management. Studies in Avian Biology, vol. 21. Cooper Ornithological Society, pp. 8-17.

Wilson, E.O., 1975. Sociobiology. Harvard University Press, Cambridge, MA, USA.

Worton, B.J., 1987. A review of models of home-range for animal movement. Ecol. Model. 38, 277-298.

Worton, B.J., 1989. Kernel methods for estimating the utilization distribution in home-range studies. Ecology 70, 164-168.

Zwicker, S.M., Walters, J.R., 1999. Selection of pines for foraging redcockaded woodpeckers. J. Wildlife Manage. 63, 843-852. 


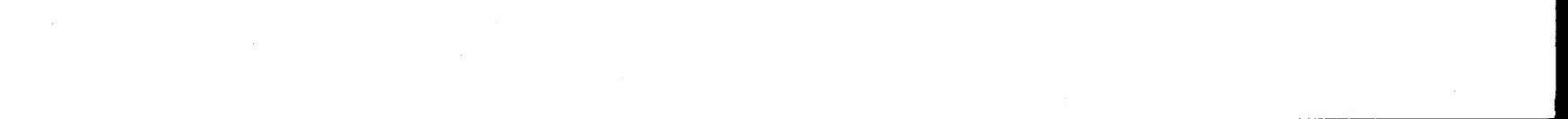

